\title{
Hybridization of Engagement Practices: Use of Communications Technology During the Quebec Red Square Movement
}

\author{
SYLVIE JOCHEMS, MELANIE MILLETTE AND JOSIANNE MILLETTE, Université du \\ Québec à Montréal
}

\begin{abstract}
Since the 1990s, engagement practices have been transforming, becoming more diverse (Ion 1997; Sommier 2003; Bobineau 2010), especially with the growing use of new communication technologies (Blondeau 2007; Cardon and Granjon 2010). In the wake of these changes, discourses insisting on a loss of community and collective action have surfaced that encourage scepticism about the potential of these technologies to support political and social engagement, arguing that communication technologies were the cause of social fragmentation and of growing individualism (Putnam 2000; Bauman 2006). Recent social movements, such as the Arab Spring, the Indignados, Occupy and the 'carrés rouges' (red square) movement in Quebec are now casting doubt on this discourse.
\end{abstract}

While many researchers have set out to examine how social movements under authoritarian regimes use social media and mobile technologies to organize, gain visibility and disseminate images of their actions around the world, the reconfiguration of collective action associated with the use of social media, and the relationship between social engagement and the use of technology in contemporary liberal democracies have been largely neglected. Technology is used in complex social, political and technological contexts that generate cultural interpretations and frameworks of practice in response to which individuals and groups stake out a space of freedom to practise resistance and appropriation (Jouët 2000; Jauréguiberry and Proulx 2011). How ICT and mobile communication uses contributed to and were embedded in the transformation of engagement practices during the carrés rouges and what it reveals about the transformations engagement practices, is the focus of the present paper.

The red square movement, launched by student strikers in Quebec in spring 2012, provides a rich opportunity to study how social movements with historical roots can embrace mobile and participatory technologies, and evolve along with their communicational environment. Based on a study of mobile and participatory technology practices used by the red squares, and using an approach midway between communications, sociology and social work research, we argue that by encouraging mobilization and coordination (Millette, Millette and Proulx 2012) and citizen expression (Monnoyer-Smith 2011), the use of social media and mobile technologies contributes to the hybridization (Bennett and Segerberg 2012; Canclini 2010) of political and social engagement practices. 


\section{RÉSUMÉ EN FRANÇAIS}

Depuis la fin des années 1990, les pratiques d'engagement se diversifient et se transforment (Ion, 1997; Sommier, 2003; Lamoureux, 2008; Bobineau, 2010), notamment en lien avec les technologies de communication (Blondeau, 2007; Cardon et Granjon, 2010 ). Or, une perspective déplorant le déclin de la vie communautaire et associative a nourri une méfiance face aux usages de ces technologies comme pratiques d'engagement social et politique, celles-ci étant considérées comme favorisant l'individualisme et la fragmentation de l'action collective (Putnam, 2000 ; Bauman, 2006). Or, de récentes mobilisations, dont les mouvements du printemps arabe (2010), des indignés (2011) et des carrés rouges au Québec (2012) remettent en cause ces discours.

Depuis la fin des années 1990, les pratiques d'engagement se sont diversifiées et transformées (Ion, 1997; Sommier 2003; Bobineau 2010), notamment en lien avec les technologies de communication (Blondeau 2007; Cardon et Granjon 2010). Une perspective déplorant le déclin de la vie communautaire et associative a nourri une méfiance face aux usages de ces technologies comme pratiques d'engagement social et politique, celles-ci étant considérées comme favorisant l'individualisme et la fragmentation de l'action collective (Putnam 2000; Bauman 2006). Or, les récentes mobilisations du Printemps Arabe, du mouvement des Indignados, d'Occupy et des carrés rouges au Québec, remettent en cause de tels discours.

Si plusieurs travaux se sont penchés sur les mobilisations citoyennes dans des contextes politiques autoritaires, pour décrire comment les médias sociaux ont notamment servi à rendre visible l'indignation et l'action citoyennes, peu de chercheurs ont abordé les reconfigurations de l'action collective associées aux usages des médias sociaux, de même que les relations entre engagement et usages des technologies dans le contexte des démocraties libérales contemporaines. Or, au-delà de la stricte manipulation des technologies, un usage s'inscrit dans un contexte social, politique et technologique d'où émergent des interprétations culturelles et des cadres de pratiques, face auxquels les individus et les collectifs conservent toutefois un espace de liberté pour pratiquer résistances et détournements (Jouët 2000; Jauréguiberry et Proulx 2011). Comment les usages des TIC mobiles ont-ils contribué et comment ont-ils été enchassés dans les transformations des pratiques d'engagement sociales et politiques pendant le mouvement québécois des carrés rouges québécois, et que cela révèle-t-il des transformations des pratiques d'engagement?

Initié par la grève des étudiant.es du Québec en 2012, le cas des carrés rouges offre l'occasion d'observer comment des mouvements s'inscrivant en continuité avec des formes de mobilisation « historiques » peuvent intégrer les technologies mobiles et participatives et se transformer avec leur environnement communicationnel. À partir d'une description des pratiques liées aux technologies mobiles et participatives déployées dans le cadre du mouvement des carrés rouges et d'une approche à l'intersection des études en communication, de la sociologie de la communication et du travail social, nous proposons ainsi de considérer que les usages de ces technologies de communication, à travers des pratiques de mobilisation, de coordination (Millette, Millette et Proulx 2012) et d'expression citoyenne (Monnoyer-Smith 2011), 
contribuent à une hybridation (Bennett et Segerberg 2012; Canclini 2010) des pratiques d'engagement sociales et politiques.

\section{KEYWORDS}

Engagement practice, communication technology, hybridization, social media, Quebec student strike, red square

\section{Introduction}

Since the 1990s, engagement practices have been transforming, becoming more diverse (Ion 1997; Sommier 2003; Bobineau 2010), especially with the growing use of new communication technologies (Blondeau 2007; Cardon and Granjon 2010). In the wake of these changes, discourses insisting on a loss of community and collective action have surfaced, fuelling scepticism about the potential for mobile and participatory communications technology $(\mathrm{ICT}+\mathrm{m})^{1}$ to support political and social engagement. These discourses frame communication technologies as a cause of social fragmentation and of growing individualism (Putnam 2000; Bauman 2006). Recent social movements, such as the Arab Spring, the Indignados and Occupy have cast doubt on such discourses.

In Québec, the carrés rouges movement, launched by striking students and buoyed by popular support during what was termed the printemps érable ${ }^{2}$ or Maple Spring, illustrates how social movements can embrace these technologies and adapt to the new communicational environment. The red square movement emerged in an Internet-enhanced public space (Cardon 2010) where it became a networking, polysemic and polymorphous citizen uprising, at once a student strike and an expression of public indignation in the face of a social and political crisis.

In the wake of citizen uprisings in the Middle East and occupations under the banners of Indignados and Occupy, several social science studies have examined the changing realities of political mobilization. Much has been written about how citizens used Twitter and Facebook, in particular, to publicize their indignation and broadcast images of their actions (see, for example, Wolfsfeld et al. 2013; Penney and Dadas 2013; Harlow 2012; Poell and Borra 2012). Little attention has been paid, however, to the reconfiguration of collective action from the prism of social media uses. We are therefore asking: in the context of the red square movement in

\footnotetext{
1 We will use the acronym ICT $+\mathrm{m}$ to refer to the mix of information communications technology (ICT) and mobile ICT.

${ }^{2}$ The expression printemps érable was widely circulated in the Quebec and international media to describe the social movement initiated by the student strike in 2012. The term clearly echoes printemps arabe (Arab Spring, which sounds similar in French), which designated mainly the Tunisian uprising that began in December 2010 and the protest movements that shook Egypt in early 2011. We prefer not to use these expressions to avoid the misunderstandings associated with them, particularly in terms of duration (in both cases, the movements began well before spring and continued long afterwards). In the case of the Maple Spring, we prefer to speak of the red square movement, in reference to the squares of red felt worn to show support.
} 
Quebec, what do the uses of ICT $+\mathrm{m}$ and social media reveal about changes in social and political engagement practices happening in liberal democracies?

Our approach to examining engagement practices in relation to the use of ICT $+\mathrm{m}$ based on the student movement that marked Quebec political life in 2012 combines communications research with theory on social movements and is informed by a social work approach. Inspired by the French current of sociology of communication technology use, and starting from our own experiences as participants in the red square movement, we wish to open a dialogue with existing frameworks for understanding collective action and social movements.

After a explanation of the red square movement, we start by presenting the works of Charles Tilly (Tilly 1986; Tilly and Tarrow 2006) and Erik Neveu (2002) on generations of repertoires of forms of engagement. In particular, the third generation of repertoires in which people engage in a more decentralized manner, will be examined through the prism of ICT $+\mathrm{m}$. We will then provide examples of both individual and collective uses of ICT $+\mathrm{m}$ observed during the red square movement, in regards to coordination and symbolic practices. Considering that these political uses of ICT $+\mathrm{m}$ reveal some co-mingling of repertoires of engagement, we will argue that hybridization is a useful concept to understand the articulation of these practices. Understanding that repertoires are not immutable and that practices can combine to give way to hybrid modes of organization should not, however, blind us to the tensions that emerge in this process.

\section{Context: "Student Strike, Popular Struggle"}

Launched in response to a second round of university tuition hikes announced in March 2010 by the Liberal government under then-premier Jean Charest, the 2012 protest became the largest strike movement, in terms of length and size, in the history of the Quebec student movement. ${ }^{3}$ In keeping with a historic tradition of a student movement that defended education in the service of the common good and that condemned student debt, and in reaction to a swing toward neoliberalism that they argued would have turned knowledge into a commodity (Sawchuk 2012), the red square movement grew over the following months. Becoming more of a popular struggle as the months went by, especially during the mass demonstrations on the $22^{\text {nd }}$ of each month, the nightly marches and demonstrations that brought neighbourhoods together for improvised

\footnotetext{
${ }^{3}$ The general unlimited strike movement (identified under the \#ggi hashtag in social media) was started in February 2012 by the member associations of the Coalition de l'Association pour une solidarite syndicale étudiante (Coalition of the Association for Student Union Solidarity, or CLASSE), joined by the Quebec university and college federations (FEUQ and FECQ) and the associations that belong to the Table de concertation étudiante du Québec (Quebec Student Round Table, or TaCEQ). Elections leading to the defeat of the ruling Liberals by the Parti Québécois put an end to the strike in September. At the time of writing, the protest remains active, the new government having decreed, amid harsh criticism at a summit on higher education in February 2013, that it will index university tuition.

${ }^{4}$ Students and other supportive citizens gathered for massive demonstrations on this date each month from February to June 2012. Although some demonstrations took place on the $22^{\text {nd }}$ of subsequent months, they did not attain the scale of those from February to June.
} 
pot-banging concerts, ${ }^{5}$ the red square movement was also the platform for a public counterdiscourse to reclaim the opportunity to truly participate in democratic life. The red square movement can therefore be understood as both a student uprising, driven by organizations that use engagement repertoires and drawing on the history of the Quebec student movement (equality for all, equality of opportunity, etc.), but also as a broader social mobilization and, by definition, comprised of a variety of practices and discourses.

As the militant base of the movement was made up of educated youth, it is no surprise that recourse to $\mathrm{ICT}+\mathrm{m}$ and social media was widespread during the conflict. While one-third (32 per cent) of Quebec adults own a smartphone, the figure is twice as many (65 per cent) among 18-to24-year-olds and 69 per cent among students (CEFRIO 2012a). In the same age group, the vast majority (75 per cent) own a personal computer and use the Internet and social media extensively. While 18-to-44-year-olds are the most active users, these technologies are nevertheless used at all levels of Quebec society (CEFRIO 2012b). ${ }^{6}$

\section{Methodological Stance}

It is appropriate here to offer a methodological clarification. We did not, strictly speaking, carry out a field survey as part of a formal research process. The observations and data presented to illustrate our critical examination of engagement practices in light of ICT $+\mathrm{m}$ use are drawn from a clearly empirical process, backed by a critical review of the literature, but above all autoethnographic. We therefore have to acknowledge that the data used come from our own experiences during the red square protests.

Auto-ethnography is the process of analysing a personal experience to uncover a broader cultural understanding (Ellis et al. 2011). More specifically, it is a self-reflective stance in which a researcher tries, with hindsight, to make sense of an especially vivid experience (ibid.). In our case, the auto-ethnographic stance emerged from the reflection triggered by our experience of the street demonstrations, the pot-banging evenings as well as intensive analysis of the Twitter feed for \#ggi (the hashtag for grève générale illimitée or 'unlimited general strike' which was one of the most popular and long-lasting) and \#manifencours (the hashtag used to describe or comment on a demonstration underway), and reading testimonies and newspaper articles posted on Facebook. Furthermore, media uses, especially those associated with mobile technologies, were particularly effective for managing movements and informing people about the various demonstration locations around the city. We saw first-hand how certain tensions and continuities occurred between different repertoires of collective action and we wanted to investigate this thread.

\footnotetext{
${ }^{5}$ One of the many spontaneous pot-banging demonstrations can be viewed at http://www.youtube.com/watch?v=0PKZG4AmX2Q\& feature=share.

${ }^{6}$ It is of interest to note, also, that the Quebec media landscape is marked by one of the greatest media ownership concentrations in the world, so content convergence is especially high, further reducing access to media space and helping intensify the struggle to be seen and to assert a claim or point of view.
} 
We chose the most rigorous approach possible, anchored and subjectivized by our own experiences and $\mathrm{ICT}+\mathrm{m}$ use, and backed by a close comparison with models from various studies on related subjects, to make sense of these reconfigurations of engagement and political mobilization practices.

\section{Being engaged: Hybridization and Repertoires of engagement}

Nestor Garcia Canclini defines hybridization to mean socio-cultural processes in which discrete structures or practices, that exist separately, combine together to generate new structures, new objects and new practices $(2010,19)$. Canclini also observes that hybridization policies can be used to work democratically with divergences (ibid., 26). Moreover, W. Lance Bennett and Alexandra Segerberg (2012) argue that we need to consider the articulation of different logics at play to understand how contemporary social movements are organized and use social media. Examining the overlaps between the traditional logics of collective action and the connective logics enabled by social media, they suggested that hybrid forms are emerging between these two ideal types. Building on these approaches, we understand hybridization of engagement repertoires as a process of intersection and transaction. We argue that this kind of hybridization, as observed in engagement practices, generates continuity as well as tensions among social actors, as we will expose further below.

Anthropologist Olivier Bobineau (2010) suggests that being engaged refers to constraining oneself and taking action. He argues that being an activist is both binding and freeing oneself through action, colliding with things by acknowledging their strength and using them to go even further. This clearly describes the tension involved in political engagement and activism, which is to allow oneself to be caught up in a situation or cause in order to denounce it and change it. Meanwhile, sociology approaches the concept of engagement mainly from the angle of analysing the dynamics of collective action and social movements. In his popular summary of this field of research, Erik Neveu (2002), drawing on the interactionist works of Herbert Blumer (1946), describes collective action as acting together in a voluntary project within a social movement - that is, concerted collective action for a cause or a new order of life. In this sense, personal engagement contributes to the creation of the collective by embodying specific forms of voluntarily organized collective action. Neveu explains that these forms of collective action play a part in the construction of social movements.

Social work usually approaches forms of collective action as intervention techniques in community settings ${ }^{7}$. Tilly and Sydney Tarrow propose to frame forms and techniques of collective action as 'relatively familiar and standardized ways in which one set of political actors makes collective claims on some other set of political actors' (2008, 332). Furthermore,

\footnotetext{
${ }^{7}$ The list of intervention techniques commonly refered to includes awareness-raising meetings, training sessions or workshops, public information sessions, theme days, conferences, public forums and summits, guerilla theatre, popular performance and neighbourhood festivals, engaged art installations and demonstrations, petitions, mass mailing, letters, text messages, activist hoaxes, booths, door-to-door canvassing, presentations to different levels of government, demonstrations, marches and vigils, flash mobs, non-cooperative action, civil disobedience, tactics of a politics of action (Lavoie, Panet-Raymond and Kruzinsky 2012).
} 
repertoires of collective action allow us to get closer to the model-based reasoning that underlies engagement, suggesting the existence of forms of institutionalization, often depicted as immutable, that are specific to social movements (Neveu 2002).

These repertoires are co-constructed by social groups: the techniques pre-exist the repertoire, but the specific combination takes shape in situated action, is enacted in practices taking place in a particular context. Thus, a collective action repertoire is defined as

an array of contentious performances that are currently known and available within some set of political actors. [For example,] England's antislavery activists helped to invent the demonstration as a political performance, but they also drew on petitions, lobbying, press releases, public meetings, and a number of other performances. (Tilly and Tarrow 2008, 101)

While Tilly and Tarrow put forward the idea of pre-existing repertoires, our view of a collective action repertoire insists more on the co-construction of new forms of action. Despite this difference, several aspects of Tilly and Tarrow's theory are relevant to our approach. First of all, their view allows us to relativize the vocabulary of innovation and novelty that is hinted in analyses and discourses on the contributions of ICT $+m$ to political action, and to highlight the importance of a 'long view' in the analysis of social movements, as Tilly (1986) recommends. Tilly also puts forward the idea of diverse generations of repertoires that can be used to expand and contextualize different forms of collective action.

Tilly (1986) identifies two generations of engagement repertoires, and we will see that our analysis aligns with a third one, offered by Neveu (2002). Just as the various waves of feminism differed in the subjects they broached and succeeded one another without the previous wave having necessarily ended, these generations of repertoires differ from one another and exist simultaneously today.

The first generation of these forms of engagement, which took shape before the industrial revolution, was the 'sponsored community' model, which co-opted and diverted pre-existing social rituals (Neveu 2002, 21). The actions were locally anchored, limited to one city or community, and the participants generally sought the backing of a dignitary who would intercede with the authorities in question. Collective actions as parody, farce and charivari belong to this first generation of forms of engagement.

The second generation of collective action repertoires was the 'autonomous national' model, epitomized in the workers' movement, which radically distanced itself from the sponsorship of figures of authority. For the second generation, authority actually became the target of the collective action (Tilly 1986, cited in Neveu 2002, 23). Here we see strikes and demonstrations emerge as the preferred forms - or even the praxis - of collective action, and programs and slogans are adopted as part of a more intellectualized, rationalized process, with a strategic plan in pursuit of a well-articulated civil society project at the national level. 
Based on Tilly's work on the first two generations of engagement repertoires, Neveu (2002) proposes to add a third one. He designates it as a derivative of the 'Seattle effect', from the name of the city where the World Trade Organization (WTO) summit was held in 1999 and which revealed clear changes in the forms of collective action (Sommier 2003). At the dawn of the third millennium, Neveu (2002) points out that collective action is going international, defying the local and national boundaries to which the previous generations of repertoires tended to limit themselves. He adds that hacktivism, or online activism, which helps to internationalise protest by facilitating transnational information networks, is one of the characteristics of this action model. Expertise is also important in the citizen engagement process: scientific, legal and technological knowledge are essential in order to mobilize around complex issues related to the environment, nuclear energy, civil rights and copyrights, for example. Consequently, Neveu (ibid.) points out that this third generation of repertoires is unique in that it combines an argued and documented process, based on expertise, with a more creative process, associated with street art and embodied in symbolic action. Symbolic action is playful and peace-abiding (which differentiates it from civil disobedience); it aims to attract attention by invading the public arena and media through the use of aestheticism and cultural referents with strong connotations (Boesch 1995; Tenenbaum 2006).

In Québec, this third generation of repertoires that combines diversity of tactics and symbolic action first emerged during the mobilization around the Summit of the Americas, in 2001. At that time, the symbolic action was carnivalesque in form, with tam-tams, fanfares, and lighthearted skits (Dupuis-Déri 2008). During the red square demonstrations, symbolic action took on added momentum with the use of pots to 'be heard' by the politicians. Residents of various neighbourhoods around the city joined in by coming out on their balconies and in the streets every evening at 8 p.m., pots and spoons in hand (Millette, Milette and Proulx 2012; Sawchuk 2012).

\section{From the normalization of social practices to new repertoires}

According to Tilly and Tarrow (2008), repertoires differ by place, time and participants. Certain engagement practices become normalized, even institutionalized, and are recognized as being classic. Social actors do not randomly select forms of engagement: established forms are not neutral but in fact carry meaning, history and their mobilization is inscribed in power relations. As such, choosing institutionalized forms of engagements contributes to the construction of the movement's identity. Consequently, changing repertoires, and particularly changing generations, is sure to provoke reactions. Each generation that pioneers new territory and differentiates itself from the previous generation, even without making a complete break, gives rise to tensions. In Québec as in other liberal democracies, nostalgic ideas along with complaints about individualism (Putnam 2000), and the break with the associative activism repertory (Ion 1997), emerged in the discursive landscape over the last few decades partly as reaction to the emergence of the third generation of repertoires. These discourses and ideas created some pressure to conform to earlier, already institutionalized repertoires. 
However, contrary discourses also circulated, casting doubt on the idea of individualism and demobilization. Like Bobineau (2010), Jacques Ion (1997) stays at prudent distance from this supposed crisis of engagement, saying attention must be paid to emerging models of engagement. Ion offers the hypothesis that activism as it has been exercised for the last century is only one mode of engagement, and that new forms of social participation are in the making that reflect the relationship between society and the individual (ibid., 12). He even questions the adequacy of the model preferred by nostalgic discourse since the classic associative activist model no longer explains the entire landscape (ibid., 79). Ion's ideas reflect the major wave of young adults who are mobilizing around the world (Indignados, uprisings in the Middle East, M15 in Mexico, student strikes in Chile, Occupy and, finally, the red square movement in Quebec). In short, different forms and meanings of engagement currently co-exist: engagement and collective action do not follow a straight line, and one model is not being substituted for another (ibid., 91), which leads to the clashing discourse between the more classic, institutionalized activist communities and new uprisings, carried out mainly by young adults.

As demonstrated by these opposing discourses, and by the development and proliferation of engagement repertoires and forms of collective action, citizen practices such as those of the red square movement provide a wealth of information for investigation. As such, we wish to examine how $\mathrm{ICT}+\mathrm{m}$ use contributes to and are embedded in the transformation of engagement practices. To do so, we mobilize the concept of hybridization to cast light on these transformations.

\section{New Relationships with ICT+m: Political Engagement Practices}

Media practices during the red square movement demonstrate a change of attitude toward $\mathrm{ICT}+\mathrm{m}$. Even though some attitudes remained polarized, from a 'be-all-and-end-all' attitude to cries of 'slacktivism' (Christensen 2011), more balanced attitudes and a certain openness were also seen among social actors and in the institutionalized protest community. In academia, a more nuanced attitude - neither techno-determinist nor socio-determinist - has also been expressed in the literature about political engagement and the Internet over the last decade. Zizi Papacharissi (2002), for example, suggests that while Internet and social media have not upset the balance of power of the big corporations and dominant conglomerates, they nevertheless offer a real possibility of organizing and facilitating resistance efforts, and to link isolated individuals (ibid., 20). Despite cooptation, Internet and ICT $+\mathrm{m}$ represent an opportunity for public participation (Papacharissi 2002, 2010; Monnoyer-Smith 2011).

Likewise, for Peter Dahlgren social media and Internet can facilitate citizen engagement, as long as media participation and political participation are not equated:

Sometimes, the media can facilitate not just engagement, but even participation, as when the Internet is used by citizens for political purposes. However, while engagement catalyzed by media representations can serve as a stepping-stone for participation, engagement in media output per se should not be confused with political participation (except, of course, where media performance itself has been made a political issue in the life of a democracy). (2009, 81) 
For Dahlgren, engagement is a complex process that is a condition for citizen participation which is itself the final phase of civic engagement. By facilitating citizen participation - for example, by making it possible to re-broadcast information, cooperate and coordinate events $\mathrm{ICT}+\mathrm{m}$ and social media have the potential to contribute to political participation.

\section{Coordination Practices: Representative Democracy and Direct Action}

Our engagement experience with the red square movement led us to consider changes in comparison with the previous generation of collective action repertoires and even in comparison with different repertoires in the current generation. It is almost impossible, though, to draw a clear boundary between these so-called third-generation technology-based repertoires and other generations of repertoires: the use of $\mathrm{ICT}+\mathrm{m}$ was consistently accompanied by off-line practices, and affinity groups traditionally associated with second-generation repertoire used these tools during the red square mobilization.

More specifically, ICT $+\mathrm{m}$ uses that we observed straddled engagement traditions linked to representative democracy and a repertoire characterized by heterogeneous individual and collective initiatives. To illustrate this crossover between repertoires, we offer a non-exhaustive review that is nonetheless meaningful in terms of the diversity of actions and practices observed during the red square mobilization.

\section{(1) Collective and individual actions}

The student strike was led by four student organizations that operated with different levels of centralization and institutionalization, and that had adopted ICT $+\mathrm{m}$ to varying degrees to communicate with their members and in the public arena in the period leading up to the mobilization in 2012. Participatory technologies were used within the red square movement to create, remix and broadcast content as a counterweight to the established political and media powers. Activist practices focused on distributing messages, analyses and information about events (such as demonstrations) and relaying media coverage of events (what a particular newspaper said about a particular demonstration).

These media practices contributed to both the movement's internal communications - with $\mathrm{ICT}+\mathrm{m}$ being used among activists to circulate information, testimony, satire and commentary on the media discourse and political strategies of the government - and its external communications in the public arena through the mass distribution options offered by social media (Twitter and YouTube were especially well-used for this purpose). In this sense, individual action quickly revealed its potential. Some student activists took individual communication actions that were linked to collective strategies. Other free radicals or citizens supportive to the student cause took initiatives on their own, without formal organization or involvement, such as replacing their Facebook profile photo with a red square. The combined weight of these two levels - organized and prepared collective actions and individual initiatives (on the part of both students within an association and ordinary citizens and activists) - created a 
mass effect ${ }^{8}$ with regard to the non-institutional media content that was circulated.

\section{(2) ICT+m for self-organization without official mediation}

Traditional media were also harnessed by the red square student associations to broadcast their message: student organizers often agreed to be interviewed, widely occupying the traditional media space. But ICT $+\mathrm{m}$ use allowed for and promoted the exercise of speaking out personally, with no official mediation, by circumventing the usual gatekeepers in the mass media and the traditional journalism system (Cardon \& Granjon 2010).

The strength of the social web is that everyone can take initiatives on an individual and decentralized basis (Proulx, Millette and Heaton 2012), encouraging a type of online engagement to offset the crisis in representation implicit in the red square mobilization. In some cases, the very relevance of communications committees in the student associations was thrown into doubt, as Facebook events proliferated without having been mandated by any authorities whatsoever. The use of the activity calendar on the CLASSE website speaks volumes in this regard. During the uprising, CLASSE offered a platform where individuals and groups could announce their own activities, demonstrations, press conferences, etc. This participatory platform was widely used and led to dozens of summits when several activities and demonstrations were held on the same day. These activities were coordinated using the social media, with no official mediation by the student organizations (here, again, the Facebook event management function was useful for avoiding duplications).

ICT $+m$ enabled mass coordination and mobilization based on individual initiatives (Millette, Millette and Proulx 2012). In the case of the red squares, Twitter provides a telling example. Since demonstrations were often halted by the police forces, having been declared to be unlawful assemblies under a new municipal bylaw, ${ }^{9}$ the use of Twitter tags, especially the previously mentioned \#manifencours (demonstration underway) and \#ggi (unlimited general strike), allowed collective actions to be coordinated by individual messages from demonstrators reporting where they were headed, where they had seen police barricades, etc. So, without any centralized coordinating authority, it was possible to mobilize a large group of people, since each of them could decide on an action (such as to occupy a certain park on a certain evening) and broadcast it to their social network using ICT $+\mathrm{m} .^{10}$

\section{(3) Roles of experts and amateurs}

The actions of Anonymous created the biggest public stir in terms of using expertise - here, computer expertise - for engagement in the red square movement. Indignant about the

\footnotetext{
${ }^{8}$ Millette, Millette and Proulx (2012) also reveal the technological potential and mass effect of unorchestrated individual initiatives and the coordination and combination of social media.

${ }^{9}$ Provincial bill project 78, and municipal by Law P6 (see

http://www.spvm.qc.ca/fr/documentation/3_1_1_actualites.asp?noAct=490).

${ }^{10}$ Word of mouth was also used, but our point here is related to the potential for communicating messages using $\mathrm{ICT}+\mathrm{m}$ and social media, a potential that, in this case, resulted in a large group of people taking to the streets for several months.
} 
announcement of bill project 78, subsequently voted in as Bill 12, which many people believed to be repressive, a Québec section of Anonymous broadcast a video ${ }^{11}$ followed by a wave of hacking into the websites of several government sites and the ruling political party.

Recognized experts in several fields also harnessed ICT $+\mathrm{m}$ on behalf of the red square movement. Thanks to their status as experts, the words of these people were sometimes received as authoritative arguments in the public debate, and sometimes also as political education: social movement sociologists, ${ }^{12}$ political journalists ${ }^{13}$ and engaged lawyers ${ }^{14}$ used their blogs or Facebook pages to analyse the situation from the point of view of their specialty or to offer critical commentary on breaking news about the social crisis.

At the same time, amateurs were also broadly invested in the media arena through the adoption of ICT $+\mathrm{m}$ and the social media. The term amateurs is not used to discredit their real, valid technological or communicational competencies but to point out that ICT $+\mathrm{m}$ enabled ordinary citizens to contribute to the debate, to the number and variety of opinions exposed, and to the organization and archiving of the movement. We observed, for example, podcast and webcast initiatives, crowdmapping or geolocation of demonstrations underway using Diametrick, tweetups, the broadcasting of engaged songs and comedy skits on YouTube, collective discussions on an engaged song thanks to Soundcloud, the creation of a student strike event timeline using Frise, a map of the media coverage using PearlTrees, an analysis of Twitter discussions using Nexalive, and so on. The user-friendliness and accessibility of these platforms and technological tools definitely contributed to their widespread adoption by citizens, not to mention of course that they are part of our media culture and draw on knowledge that is already in place. ${ }^{15}$

\section{(4) Mobilization as the result of an affinity and confinity process}

Citizen affinity groups and identity-based alliances (such as groups of teachers, mothers, seniors, and feminists) ${ }^{16}$ were important players in the red square movement. These non-student movements required some coordination, if only to turn up at the same place and the same time to accomplish a particular action (march, occupy, etc.). At the same time, many students and citizens were present in the public arena night after night for the marches or province-wide demonstrations on the $22^{\text {nd }}$ of each month, without any intention of identifying themselves under a particular banner. Friendship and connection therefore contributed to a confinity process - that is, voluntary, affinity-based and shared (Bobineau 2011) - outside of the identity-based groups related to activist organizations. This decentralized coordination based on individual confinity

\footnotetext{
${ }^{11}$ The video, in which Anonymous announces its intentions can be viewed at http:/quebec.huffingtonpost.ca/2012/05/20/anonymous-operation-quebec n 1531489.html.

${ }^{12}$ For example, see Marc-André Cyr's 'social movements' blog: http://voir.ca/marc-andre-cyr/

${ }^{13}$ For example, see Josée Legault's Twitter account: https://twitter.com/JoseeLegault

${ }^{14}$ Association des juristes progressistes (see http://ajpquebec.org/)

${ }^{15}$ For example, Bonenfant, Glinoer and Lapointe (2013) shows that the students were extremely creative in the tactics and symbolic actions used. These initiatives were often related to the students' field of study: students in textile design knitted posters, journalism students created a journalistic blog, film students created documentaries and video clips, etc.

${ }^{16}$ Profs contre la hausse, Mères en colère et solidaires, Têtes blanches et carrés rouges, Féministes contre la hausse were particularly prominent.
} 
initiatives offered an important practical function: since the demonstrations were often required to disperse rapidly (due to orders from police authorities, the use of tear gas, etc.), it was easier to mobilize in pairs or small groups of friends. Here again ICT $+\mathrm{m}$ was an effective tool for facilitating communication during actions, to meet up in the city, prevent possible arrests on the next street corner, and so on.

\section{Social Criticism, Artistic Criticism and Symbolic Practices}

The student red square movement, which the pot-bangers joined, helped put the social cause in the spotlight of Quebec political debate, which had long been centred on the traditional separatist-federalist question. Luc Boltanski and Eve Chiapello (1999) define social criticism as the struggle against the misery and inequalities arising from the egoism of individual interests. The opposition between the red squares and students opposed to the strike was telling in this regard. The red squares were calling for the maintenance of public policies based on social justice that see education as more than a commodity and insist tuition fees should not serve a commercial end. The students who accepted the tuition increases, who rallied under the banner of the green squares, turned to the courts to defend their individual right to an education, as clients of educational institutions.

It is important to note that the red square movement also exerted a second form of criticism, while symbolic actions were proliferating day after day both in the streets ${ }^{17}$ and initiated or relayed in the social media. This second criticism could be conceived as artistic criticism as it denounced the inauthenticity of the consumer society and the suffocation of the individual's creative capacity (ibid.). It was this artistic criticism that produced many original, subversive and sometimes even spectacular ${ }^{18}$ counter-cultural actions, including the initiatives of the École de la Montagne rouge and Rabbit Crew. ${ }^{19}$

\subsection{Expressivity and testimony}

Another important aspect of the engagement practices used during the red square movement was the possibility, in the context of third-generation engagement repertoires, of being both the reader-author-receiver and recipient of messages in circulation. Castells has termed this manyto-many dynamic 'mass self-communication' (2006; 2012). Since web access facilitated citizen action without mediation in the public sphere, mandated representation by a third party, such as a public personality, expert, spokesperson or elected official, was no longer required for people to express themselves. However, this does not mean that traditional representation becomes completely obsolete, since the spokespeople of the student organizations, for example, got far

\footnotetext{
${ }^{17}$ See, for example, the ironic right-wing demonstration on April 1, 2012, by 'the Super-Rich Students' Movement' (http://www.youtube.com/watch?v=R62IoF5WY6I)

${ }^{18}$ For an example of the 'ma-nu-festations' (de-nude-strations), see http://www.lapresse.ca/actualites/dossiers/conflit-etudiant/201205/03/01-4521744-des-manifestants-tout-nusbravent-la-pluie.php.

${ }^{19}$ For the École de la Montagne rouge, see http://ecolemontagnerouge.com/about/; for Rabbit Crew, see https://www.facebook.com/LapinCrew
} 
more visibility in terms of media attention than the average protestor. Accordingly, the case of the student mobilization allows us to observe that some forms of engagement now include a major expressive component (Monnoyer-Smith 2011). These practices are both political and cultural, and they put forward the voice, opinion and subjectivity of the author, as demonstrated by memes ${ }^{20}$ and the remixed and original videos that circulated.

ICT $+\mathrm{m}$ was also used extensively for testimony, to allow participants to own the narrative of the movement and to co-construct its memory. The practices observed, including archiving ${ }^{21}$ and recording the chronology of events, are revelatory in this regard. They counter-balanced the dominant media and political discourses by circulating images and narratives that we believe censorship or media framing would not have permitted the public to see or understand. ${ }^{22}$ The hashtag \#manifencours not only facilitated coordination and expression, but was also used to publish collective testimonies. In this case, the testimonies were built actively, not only from the point of view of the participants testifying about their own experience, but especially from the point of view of the network of people who were passing around these testimonies, commenting on them and adding their own.

The violent repression that occurred during the protests gave the many testimonies in social media an especially relevant purpose in relation to democracy and representation. Key moments such as the demonstration against the Liberal government's Plan Nord, the demonstration in Victoriaville during the Liberal Party congress, and the 135 consecutive night marches were massively documented and commented upon on Twitter, Facebook and YouTube. Another widespread practice was sharing videos of demonstrations and police actions in social media. Individuals and groups set up spaces online to archive testimonies, in order to create collaborative investigations that would not only serve a political and media purpose ${ }^{23}$ but also a legal one.

\section{Discussion: Hybridization Practices?}

We argue that hybridization is a useful concept to understand practices that, during the red square movement, revealed a lack of clear differentiation among engagement repertoires. Indeed, these practices maintain a connection with the heritage of the engagement practices more traditionally associated with the second and first generations of repertoires, while they show new combinations adapted to the particular context.

It is worth bearing in mind that third-generation engagement repertoires are not exclusively

\footnotetext{
${ }^{20}$ For example, see the UQAM meme at http://uqammemes.wordpress.com/.

${ }^{21}$ For example, see

http://fr.wikipedia.org/wiki/Gr\%C3\%A8ve_\%C3\%A9tudiante_qu\%C3\%A9b\%C3\%A9coise_de_2012.

${ }^{22}$ See, for example, the videos 'Le printemps québécois: quand le peuple s'éveille...' ('Quebec spring: when the people wake up'), broadcast on March 22, 2013, at http://vimeo.com/47205376, and 'Dérives' ('Drift'), at http://www.youtube.com/watch?v=9iZdAdczrGk.

${ }^{23}$ See, for example, G.A.P.P.A., a group of citizens that aims to 'watch, broadcast and fight' for social justice. They were active during the red square movement on Twitter (http://witter.com/GAPPAsquad), Facebook (http://www.facebook.com/GAPPAsquad) and on a blog (http://gappasquad.wordpress.com/).
} 
characterized by ICT $+\mathrm{m}$ use. As Bennett and Segerberg (2012) argue, some ICT $+\mathrm{m}$ engagement practices flow from traditional repertoires and the realities of the off-line media and political landscape. They make a compelling case for the importance of considering the harmonization and circulation of offline media content and online networks, as well as the hybridization of the communicational intentions of second- and third-generation engagement repertoires. It is common to see movements using online platforms for broadcast purposes - that is, to publish from a central organization through networks (such as press releases and calls to action) - and as relays for "traditional" forms of mobilization (online petitions, tracts, posters to print). As shown by the experience of the red squares movement, the repertoires of collective action that predate the development and spread of ICT $+\mathrm{m}$ are not disappearing. They continue to be present, although their role and position may differ for each social movement and depending on context.

On the other hand, relating to the use of ICT $+\mathrm{m}$ and the logics it entails, the "new" repertory also creates some tensions, among actors on opposing sides and among actors within a single movement or organization. Some of these tensions are embodied, as mentioned earlier, in nostalgic discourses that attest to the institutionalization of the more "classic" engagement repertoires. The many uses of ICT $+\mathrm{m}$ by different actors in the red square movement certainly came up against this negative attitude in certain activist and community groups. Technophilia does cause negative reactions amongst a number of people:

This is an often especially violent position that is expressed in many political, scientific and media groups about the Internet and its activist uses. This position is so dominant, even in organizations that use the Internet intensively, that some internet activists are often obliged to adopt a tactical discourse. (Blondeau 2007, 15 ; authors' translation)

This kind of reaction is a reminder that witnessing hybrid forms of engagement repertoires should not blind us to the emerging tensions ensuing from the different processes involved in negotiating among these political and social repertoires. Moreover, investigating the matter through the concept of hybridization directly challenges to the idea of immune engagement repertoires. Practices that have been instituted, or even institutionalized, could be harnessed and converted; but if the combination of practices is perceived as invalid by those who see classic repertoires as immutable, then there is little room left to experiment with new forms of engagement and repurpose the previous forms.

The practices that embody this hybrid repertory do destabilize some actors who identify strongly with previous generations of repertoires or who consider political action solely in their light. At different moments during the red square movement, we noted a difficulty in the mass media and representatives of traditional political structures to explain and react to movements that have no officially designated leaders and that are riddled with divisions between different factions, like CLASSE. This became particularly evident when CLASSE spokespeople were asked by the government to take a stance against what was deemed violent actions. They were wildly chastised when they refused to do it, arguing their members did not mandate them to do so. 
Also, the Quebec government used the CLASSE collective online calendar of independent initiatives as the reason to break off the tense negotiations with the group's leaders and expel its representatives from the negotiating table, alleging that the organization had promoted an illegal demonstration, threatening actions and violence. CLASSE tried to explain that it used decentralized operations and had no desire (or even possibility) of exerting control over its members or being able to censure them, but the Minister of Education and many other commentators held tight to a concept of traditional negotiating practices to cast doubt on the credibility, legitimacy of the organization and even to suggest it was a threat.

The co-existence and hybridization of practices became part of the political tension even within the red square movement, among the provincial student organizations and among different segments of the membership, creating lines of dissent and power struggles. ICT $+\mathrm{m}$ are used in a social, political and technological context from which cultural interpretations and frameworks of practice emerge, in response to which individuals and groups maintain a free space to practise resistance and diversion (Jouët 2000; Jauréguiberry and Proulx 2011). Consequently, repertoires of practice are adopted in specific ways, relating to a particular social and political engagement setting, that is, a cultural setting, imbued with specific political orientations and driven by networks of relationships, power relations, tensions and individual identities. To understand how practices and hybrid repertoires emerge and evolve, the asymmetries within a single organization or movement must be acknowledged. Maintaining horizontality in a movement's organization (Tufekci 2011) requires constant, self-reflective effort, but tensions nevertheless arise between the idea of decentralized participation and the pursuit of pragmatism, efficiency, durability and political progress (Freeman 1972; Tufekci and Wilson 2012).

\section{Conclusion}

The red square movement offers the opportunity to observe how movements building on historical or classic forms of mobilization can use mobile and participative communication technologies and transform themselves along with their communicational environment. Based on the practices related to the ICT $+\mathrm{m}$ deployed in the red square movement, we have suggested that the use of these tools, through mobilization, coordination and citizen expression practices, contributes to the hybridization of engagement repertoires. The red square movement embodied such hybridization. During the strike, collective action that reflected the classic plan for an organization with clear, generally centralized structures and practices organized in a relationship of cohabitation and mutual influence with decentralized and non-hierarchical organisation. The individualized engagement practices, connected in networks, did not replace or erase previous repertoires nor the power relations or cultures of activist groups where they developed. Rather, they were both in tune and in tension with them. The forms they took and the roles they played in the trajectory of the movement were the result of the negotiation they underwent, the way they were mobilized in a specific context and the way they were expressed in the repertoires, structures and cultures of the groups involved.

Further analysis of these practices is required, using a variety of approaches, to debate and 
clarify the different configurations that citizen engagement can take. It would be especially useful to investigate how power relations or activist cultures and histories are allowing certain groups and movements to enact these hybridization processes more easily while creating more tensions, or even dysfunctions, for others. This article was written with the intention of launching such a discussion.

\section{References}

Bauman, Z. (2006) La vie liquide, Rodez: Éditions du Rouergue/Chambon

Bennett, W. L., and Segerberg, A. (2012) 'The Logic of Connective Action', Information, Communication \& Society, 15(5), 739-68

Blondeau, O. (2007) Devenir media: L'activisme sur Internet, entre défection et experimentation, Paris: Éditions Amsterdam

Blumer, H. (1946) 'Collective Behavior', in A. M. Lee (ed.), New Outline of the Principles of Sociology, New York: Barnes and Noble

Bobineau, O. (2011) 'La troisième modernité, ou "l'individualisme confinitaire", SociologieS: Théories et recherches, [online]. Accessible at http://sociologies.revues.org/3536

Bobineau, O. (2010) Les formes élémentaires de l'engagement: Une anthropologie du sens, Agnières: Éditions Temps présent

Boesch, E.E. (1995) L'Action symbolique: Fondements de psychologie culturelle Paris: Editions L'Harmattan

Boltanski, L., and Chiapello, E. (1999), 'De l'esprit du capitalisme et du rôle de la critique: Le capitalisme et ses critiques', in Le nouvel esprit du capitalisme, Paris: Gallimard, pp. 69-86

Bonenfant, M., Glinoer, A. and Lapointe, M.-E. (2013) Printemps québécois: Une anthologie, Montreal: Éditions Écosociété

Canclini, N.G. (2010) 'Cultures hybrides: Stratégies pour entrer et sortir de la modernité', F.B. Gonzalez (trans.), Quebec City: Presses de l'université Laval, [1989]

Cardon, D. (2010) La démocratie Internet: Promesses et limites, Paris: Éditions du Seuil

Cardon, D. and Granjon, F. (2010) Médiactivistes, Paris: Presses de Sciences Po

Castells, M. (2006) 'Emergence des "médias de masse individuels", Le Monde diplomatique, [online]. Available from http://www.monde-diplomatique.fr/2006/08/CASTELLS/13744

Castells, M. (2012) 'Ni dieu ni maître : les réseaux', Working Papers Series, Fondation Maison des Sciences de l'Homme, 2, 1-10.

CEFRIO (2012a) 'NETendances 3: La mobilité au Québec, une tendance en croissance', [online]. Available from

http://www.cefrio.qc.ca/fileadmin/documents/Rapports/NETendances_3_MR_FINAL2012121 $0 . p d f$

CEFRIO. (2012b) 'NETendances 1 : Les médias sociaux ancrés dans les habitudes des Québécois', [online]. Available from 
http://www.cefrio.qc.ca/fileadmin/documents/Rapports/NETendances_1reseaux_sociaux_LR_.pdf

Christensen, H.S. (2011) 'Political Activities on the Internet: Slacktivism or Political Participation by Other Means?', First Monday, 16, [online]. Available from http:/firstmonday.org/htbin/cgiwrap/bin/ojs/index.php/fm/article/viewArticle/3336/2767

Dahlgren, P. (2009) Media and Political Engagement: Citizens, Communication and Democracy, Cambridge: Cambridge University Press

Dupuis-Déri, F. (ed.) (2008) Québec en mouvements: Idées et pratiques militantes contemporaines, Montreal: Lux Éditeurs

Ellis, C., Adams, T. E. and Bochner, A. P. (2011) 'Autoethnography: An Overview', Forum: Qualitative Sozialforschung/Forum: Qualitative Social Research, 12(1). Accessible at http://www.qualitative-research.net/index.php/fqs/article/view/1589

Freeman, J. (1972) 'The Tyranny of Structurelessness', Berkeley Journal of Sociology, 17, 15165. Accessible at http://www.jofreeman.com/joreen/tyranny.htm

Harlow, S. (2012) 'Social Media and Social Movements: Facebook and an Online Guatemalan Justice Movement that Moved Offline, New Media \& Society, 14(2), 225-43

Ion, J. (1997) La fin des militants?, Paris: Les éditions ouvrières

Jauréguiberry, F., and Proulx, S. (2011) Usages et enjeux des technologies de communication, Toulouse: Érès

Jouët, J. (2000) 'Retour critique sur la sociologie des usages', Réseaux, 18(100), 487-521. Accessible at http://www.persee.fr/web/revues/home/prescript/article/reso_07517971_2000_num_18_100_2235

Lavoie, J., Panet-Raymond, J. and A. Kruzynski (2012) 'La sensibilisation, la mobilisation et les moyens de pression', in Panet-Raymond et Lavoie (ed.), La pratique de l'action communautaire, Ste-Foy: Presses de l'Université du Québec, pp. 161-227

Millette, M., Millette, J. \& Proulx, S. (2012) 'Hashtags et casseroles: De l'auto-organisation du mouvement social étudiant', WI: Journal of Mobile Media, [online], 9 June. Accessible at http://wi.mobilities.ca/hashtags-et-casseroles-de-lauto-organisation-du-mouvement-socialetudiant/

Monnoyer-Smith, L. (2011) 'La participation en ligne, révélateur d'une évolution des pratiques politiques?', Participations, 1(1), 156-85

Neveu, E. (2002) Sociologie des mouvements sociaux, 4th ed., Paris: Collection Repères

Papacharissi, Z. (2010) A Private Sphere: Democracy in a Digital Age, Cambridge and Malden: Polity Press

Papacharissi, Z. (2002) 'The Virtual Sphere: The Internet as a Public Sphere, New Media \& Society, 4, 9-27

Penney, J. and Dadas, C. (2013) '(Re)Tweeting in the Service of Protest: Digital Composition and Circulation in the Occupy Wall Street Movement', New Media and Society, [online], March 15. Accessible at

http://nms.sagepub.com.proxy.bibliotheques.uqam.ca:2048/content/early/2013/03/13/146144481 
3479593

Poell, T. and Borra, E. (2012) 'Twitter, YouTube, and Flickr as Platforms of Alternative Journalism: The Social Media Account of the 2010 Toronto G20 Protests', Journalism, 13(6), 695-713

Proulx, S., Millette, M., and Heaton, L. (eds) (2012) Médias Sociaux: Enjeux Pour la Communication, Quebec City: Presses de l'université du Québec

Putnam, R. D. (2000) Bowling Alone: The Collapse and Revival of American Community, New York: Simon \& Schuster

Sawchuk, K. (2012) 'Commentary: La grève est étudiant/e, la lutte est populaire: the Québec Student Strike’, Canadian Journal of Communication, 37, 499-504

Sommier, I. (2003) 'Forward', in Le renouveau des mouvements contestataires à l'heure de la mondialisation, Collection Champs. Paris: Éditions Flammarion, pp. 15-34

Tenenbaum, N. (2006) 'Contestation altermondialiste et "nouvelles" formes d'engagement dans l'espace public: Comment les altermondialistes réinventent leur répertoire d'action collective? Enquête au sein du groupe Vamos!', in P. W. Boudreault (ed.), L'identité en miettes: Limites et beaux risques politiques aux multiculturalismes extremes, Montreal: L'Harmattan, pp. 89-97

Tilly, C. (1986) La France conteste de 1600 à nos jours, Paris: Fayard

Tilly, C. and Tarrow, S. (2008), Politique(s) du conflit: de la grève à la révolution, Paris: SciencesPo, Les Presses

Tilly, C., and Tarrow, S. (2006) Contentious Politics, Boulder, CO: Paradigm Publishers

Tufekci, Z. (2011) 'Can “Leaderless Revolutions” Stay Leaderless?: Preferential Attachment, Iron Laws and Networks', TechnoSociology.org, [online]. Accessible at http://technosociology.org/?p=366http://technosociology.org/?p=366

Tufekci, Z., and Wilson, C. (2012). Social Media and the Decision to Participate in Political Protest: Observations From Tahrir Square. Journal of Communication, 62 (2), 363-379.

Wolfsfeld, G., Segev, E. and Sheafer, T. (2013) 'Social Media and the Arab Spring Politics Comes First', The International Journal of Press/Politics, 18(2), 115-37 